Military Technical College

Kobry El-Kobbah, Cairo, Egypt

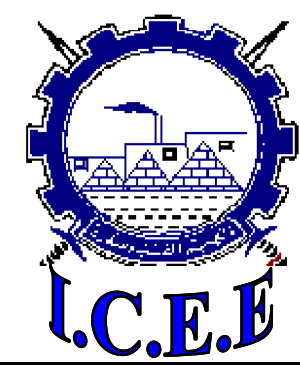

EE-2 $5^{\text {th }}$ International Conference on

Chemical \& Environmental

Engineering

\title{
AN INVESTIGATION ON THE REMOVAL OF NITROPHENOL ONTO CARBON OBTAINED FROM TREES BRANCHES
}

Ebrahiem E. Ebrahiem*, Joseph Y. Farah** and Mohammad. S. Mahmoud*

\begin{abstract}
The ability of the carbon derived from trees branches was investigated. The carbons (Olive carbon, OC, Acacia carbon, AC, and Eucalyptus carbon, EC) were prepared by thermal pyrolysis of corresponding tree branches. The experimental isotherms data were correlated using Langmuir, Freundlich and Temkin isotherm models. In the evaluation of the data, a best-fit isotherm was obtained for the system using two error analysis methods, Temkin model gives the best agreement with experimental isotherms data obtained. Subsequently, Fixed-bed column experiments have been carried out. Two simplified design models, namely, BDST model and EBRT analysis have been used to analyze the data. The column studies data has a good agreement with the BDST model. The model can be used to predict the break time at different bed height.
\end{abstract}

\section{Keywords}

Adsorption isotherm, Olive carbon, Acacia carbon, Eucalyptus carbon, Nitrophenol, Fixed bed design.

* Department of Chemical Engineering, Faculty of Engineering, Minia University, Egypt

** Departments of Chemical Engineering and Pilot Plant, National Research Center, Cairo,Egypt. 


\section{INTRODUCTION}

The pollution of water reservoirs and aquatic environment by chemicals is a dramatic problem in these last years. Phenolic compounds are habitual contaminants because they are widely used as solvents and chemical cleaning agents. They represent an environmental problem because of their toxicity, poor biodegradability and accumulation potential in plant and animal tissues [1,2]. In addition, they may enter into the food chain and have been classified as hazardous pollutants because of their potential to harm human health [3]. Thus, they must be degraded to below environmentally accepted levels before safe disposal to public health.

Phenolic hydrocarbons including nitrophenol are widely used in pharmaceutical, petrochemical, and other chemical manufacturing processes. Due to its harmful effects, wastewaters containing phenolic compounds must be treated before being discharged to receiving water bodies. The secondary biological treatment processes are commonly used for domestic and industrial wastewaters, however, they cannot treat phenolic wastewaters at high concentrations successfully. Therefore, new treatment technologies are still constantly researched and developed. Research efforts include various technologies, such as biodegradation [4], adsorption [5], catalytic wet oxidation [6], advanced oxidation processes (AOPs), etc., have been conventionally used for phenolic compounds treatment. Because phenols are harmful to organisms, disrupting energy conversion processes in cellular and subcellular membranes even at low concentrations, biological treatments have a limited capacity for degrading them, especially when the phenols are at high concentrations [7]. Although many different methods have been proposed to eliminate phenolic compounds and other organic contaminants from wastewater, the use of activated carbons, as adsorbents, is the most extended. The major disadvantages of using these carbons are its high capital and regeneration cost. Extensive research has been conducted to develop new adsorbent materials to remove the nitrophenol from wastewater. Various types of adsorbents, such as clay [8], polymeric adsorbents [9], chitosan and modified chitosan [10], charred saw-dust [11] have been developed.

The aim of this study is to investigate the possibility of removal of nitrophenol from wastewater using carbon produced by thermal pyrolysis of the residues of olive, acacia and eucalyptus trees branches as adsorbents.

\section{Materials and Methods}

\subsection{Adsorbate}

Nitrophenol (NP) with purity greater than $99.5 \%$ (Fluka Chemical Corp., Switzerland) and distilled water were used to prepare the aqueous solutions for the tests in this study.

\subsection{Adsorbent}

Three types of carbon produced from trees branches were used. The tree-origins are olive, acacia and eucalyptus. The carbons (Olive carbon, Acacia carbon, and Eucalyptus carbon) were produced by thermal pyrolysis of these tree branches at $500{ }^{\circ} \mathrm{C}$ for $5 \mathrm{hr}$, and then carbons were grounded and sieved with US Standard screens to obtain 8-16 mesh fractions. Finally, the carbons were dried in an oven at $110{ }^{\circ} \mathrm{C}$ to constant weight before use.

\subsection{Isotherm studies}

To determine the adsorption isotherms, constant weight of carbon $(0.5 \mathrm{~g})$ was added to $30 \mathrm{ml}$ of nitrophenol of desired concentration (10 to $40 \mathrm{mg} / \mathrm{l})$ in Stoppard Erlenmeyer flask. The flasks were placed in a shaker at $25 \pm 2{ }^{\circ} \mathrm{C}$ for 3 days to attain equilibrium. 
After this period of time the samples were filtered and the nitrophenol concentrations were analyzed by UV-Visible Spectrophotometer (8700 series Unican UV/V) that gave good linearity for the absorbance versus NP concentration at its maximum absorbance wavelength $365 \mathrm{~nm}$. The amounts of nitrophenol adsorbed onto the carbon were calculated from the following equation [12]:

$$
\mathrm{q}_{\mathrm{e}}=\mathrm{V}\left(\mathrm{C}_{0}-\mathrm{C}_{\mathrm{e}}\right) / \mathrm{M}
$$

Where $\mathrm{q}_{\mathrm{e}}$ is the nitrophenol uptake at equilibrium $(\mathrm{mg} / \mathrm{g}), \mathrm{C}_{\mathrm{o}}$ the initial nitrophenol concentration $(\mathrm{mg} / \mathrm{l}), \mathrm{C}_{\mathrm{e}}$ the equilibrium nitrophenol concentration $(\mathrm{mg} / \mathrm{l})$, and $\mathrm{M}$ is the mass of the carbon $(\mathrm{g})$.

\subsection{Column studies}

For the design of an industrial scale fixed-bed adsorber system, column operation is an absolute must. The column studies were aimed at evaluating the effect of various process parameters, such as the bed depth $(10,15,20$ and $25 \mathrm{~cm})$ and different flow rates.

A glass column of $50 \mathrm{~cm}$ length, $3 \mathrm{~cm}$ internal diameter was used to contain the carbon as a fixed-bed adsorber. The bed was supported on stainless steel and graded glass bed, which ensures good liquid distribution, another screen/glass bed arrangement was used at the top of the bed to prevent the disturbance of the bed. The nitrophenol solution was fed through the bed of carbon in up-flow mode to avoid channeling of the effluent. Four sampling points were fitted at $5 \mathrm{~cm}$ intervals to facilitate withdrawing of $3 \mathrm{ml}$ samples of solution by syringe at different bed heights. Finally, the effluent solution was discharged to the drain (Figurte 1).The column experiments were carried out under initial adsorbate concentration $(40 \mathrm{mg} / \mathrm{l})$ for different flow rates $(50,100$ and $150 \mathrm{ml} / \mathrm{min})$ at room temperature $25 \pm 2^{\circ} \mathrm{C}$.

As the adsorbate solution nitrophenol passes through the column of (AC), the adsorption zone (where the bulk of the adsorption takes place) starts moving out of the column and the effluent concentration start rising with the time. This is termed as break point. The breakthrough time $\left(t_{b}\right)$ for each of the column operations was defined as the time when the effluent concentration $\left(\mathrm{C}_{\mathrm{e}}\right)$ of nitrophenol reaches certain value of the feed concentration $\left(\mathrm{C}_{\mathrm{o}}\right)$. Breakthrough curves were plotted-giving ratio of effluent to feed concentrations $\left(\mathrm{C}_{\mathrm{e}} / \mathrm{C}_{\mathrm{o}}\right)$ and time for varying operation conditions. The analysis of the breakthrough curve was done using the bed depth service time model (BDST).

\section{Results and Discussion}

\subsection{Sorption Isotherms}

The isotherms belonging to the nitrophenol adsorption on the three types of carbons are given in Figure 2. It was found that the adsorption capacities order were 78, 107 and $88 \mathrm{mg} / \mathrm{g}$ for $\mathrm{OC}, \mathrm{AC}$ and EC respectively.

Freundlich, Langmuir and Temkin are the isotherms used in this study to describe the adsorption characteristics of sorbent and the linear forms of isotherms are given in Table 1. 


\subsubsection{Langmuir isotherm}

Langmuir constants $\mathrm{a}_{\mathrm{L}}, \mathrm{k}_{\mathrm{L}}$ can be determined from the linear plots of $\mathrm{C}_{\mathrm{e}} / \mathrm{q}_{\mathrm{e}}$ versus $\mathrm{C}_{\mathrm{e}}$. The essential feature of Langmuir can be expressed in terms of dimensionless constant separation factor $\mathrm{R}_{\mathrm{L}}$ which was defined by Weber and Charkravorti [15] as:

$$
R_{L}=\frac{1}{1+C_{0} a_{L}}
$$

Where $a_{L}$ is the Langmuir constant and $C_{o}$ is the initial concentration of nitrophenol $(\mathrm{mg} / \mathrm{l})$. Valves of $R_{L}$ indicate the shape of the isotherm to be either unfavorable $\left(R_{L}>1\right)$, linear $\left(R_{L}=1\right)$, favorable $\left(0<R_{L}<1\right)$ or irreversible $\left(R_{L}=0\right)$.

The calculated values of Langmuir constants $\mathrm{a}_{\mathrm{L}}$ and $\mathrm{k}_{\mathrm{L}}$ are listed in Table 2. The correlation coefficient $(\mathrm{R})>0.9$ indicated the applicability of Langmuir isotherm for the sorption data. The dimensionless constant separation factor values, $\mathrm{R}_{\mathrm{L}}$, were calculated and given in Table 2. The $R_{L}$ values lying between 0 and 1 indicate the favorable conditions for adsorption for the three carbon types [16].

\subsubsection{Freundlich isotherm}

The values of Freundlich isotherm constants, namely $n$ and $K_{f}$ are listed in Table 3 . The values of $n$ are greater than 1 indicated favorable conditions for adsorption [16]. The higher correlation coefficient values showed that the Freundlich isotherm fitted well with the experimental data.

\subsubsection{Temkin isotherm}

Experimental equilibrium data have been also analyzed using Temkin isotherm and the constants were determined and listed in Table 4.

\subsection{Error analysis}

The use of the correlation coefficient is limited to solving linear forms of isotherm equation, which measure the difference between experimental data and theoretical data in linear plots only, but not the errors in isotherm curves.

Due to the inherent bias resulting from linearization, an error function was defined to enable the optimization process to determined and evaluate the fit isotherm to the experimental data. In the context of the current work the error function used was the Marquardt's percent standard deviation (MPSD) [17].

$$
100 \sqrt{\frac{1}{n-p} \sum\left(\frac{\left(q_{e, \exp }-q_{e, c a l}\right)}{q_{e, \exp }}\right)^{2}}
$$

This error function is similar in some respects to a geometric mean error distribution modified according to the number of degrees of freedom of the system, where $\mathrm{N}$ is the number of the data points; $\mathrm{p}$ is the number of the isotherm parameters

Comparing the results of error function equation listed in Table 5, it is clear that Temkin results represent the lowest values, which means that Temkin model gives the best agreement with experimental isotherms data obtained. 


\subsection{Bed studies}

Fixed bed column adsorption studies have been carried out using aqueous solution from nitrophenol and the carbon prepared from Acacia using different flow rates. The results are plotted in terms of dimensionless liquid-phase concentration, $C_{\mathrm{e}} / \mathrm{C}_{\mathrm{o}}$, versus contact time as shown in Figures 3 to 5.

The effect of changing the flow rate has been studied at $20 \%$ breakthrough, Figure 6 . It is observed that the breakthrough time decreases with increasing flow rate of the aqueous solution of nitrophenol.

\subsubsection{Bed Depth Service Time (BDST)}

In the operation of fixed-bed adsorption column, the service time, ST, of the bed can be related to the bed depth, $\mathrm{BD}$, for a given set of conditions by a model, which offers a rapid method of designing fixed bed columns. From the BDST model, the service time of a column is given by [19]:

$$
t=\frac{N_{0}}{C_{0} U} Z-\frac{1}{k_{a} C_{0}} \ln \left(\frac{C_{0}}{C_{t}}-1\right)
$$

Where, $\mathrm{t}$ is the bed service time in min., $\mathrm{Z}$ is the bed depth in fixed bed in $\mathrm{cm}, \mathrm{N}_{\mathrm{o}}$ is the adsorption capacity in BDST model in $\mathrm{mg} / \mathrm{dm}^{3}, \mathrm{C}_{\mathrm{o}}$ is the initial concentration of nitrophenol in $\mathrm{mg} / \mathrm{dm}^{3}, C_{t}$ is the concentration of nitrophenol at time $t$ in $\mathrm{mg} / \mathrm{dm}^{3}, U$ is the linear flow rate in $\mathrm{cm}^{3} / \mathrm{min}, \mathrm{K}_{\mathrm{a}}$ is the adsorption rate constant in BDST model in $\mathrm{dm}^{3} / \mathrm{mg}$. Equation (4) may be simplified to

$$
t=m_{x} Z+C_{x}
$$

Where

$$
m_{x}=\frac{N_{0}}{C_{0} U} \text { and } C_{x}=\frac{1}{k_{a} C_{0}} \ln \left(\frac{C_{0}}{C_{t}}-1\right)
$$

The slope of the equation (5), $\mathrm{m}_{\mathrm{x}}$ may be used to predict the performance of the bed if there is a change in the flow rate. Hutchins [20] suggested that the new slope of the predicted performance at different flow rate is equal to the original slope multiplied by the ratio of the original and new flow rate. The effect of percent breakthrough has been studied at breakthrough values of 10,20 and $30 \%$ of the inlet concentration and the time taken for the select percentage at different bed depth has been measured. The plots are shown in Figure 7.

\subsubsection{Performance prediction for adsorption column}

Using the theoretical equation derived by employing the relation in BDST model, theoretical line of different flow rate can be predicted. Figure 8 shows the BDST results obtained by theoretical predicted lines and this is compared with experimental data. This gives a good agreement between the experimental and predicted column performance.

\subsubsection{EBRT Model:}

Empty bed residence time, EBRT, model is a design procedure used to determine the optimum adsorbent usage in the fixed-bed adsorption column. McKay [21] proposed that the 
capital and operating costs of the adsorption system are almost entirely dependent on the two primary variables (time required to fill the column and exhaustion rate) for fixed bed liquid flow-rate, impurity concentrations and adsorbent characteristics.

The EBRT is the time required for the liquid to fill the column, on the basis that the column is empty, no adsorbent packing,

$$
\text { EBRT }=\frac{\text { Bed Volume }}{\text { Volumeteri c Flow rate of the Liquid }}
$$

The adsorbent exhaustion rate is the weight of liquid treated at the time breakthrough occurs. That is:

$$
\text { AdsorbentExhaustion Rate }\left(\mathrm{g} / \mathrm{dm}^{3}\right)=\frac{\text { Mass of Adsorbent Used }}{\text { Volume of Liquid Treated at Breakthrou gh }}
$$

These two variables are plotted and a single line relating these two variables is called the operating line which has a minimum retention time and minimum adsorbent exhaustion rate obtained from the operating lines.

Figure 9 shows that there is a significant gain in the exhaustion rate using on reducing the nitrophenol solutions flow rates. It was observed that, the (AC) exhaustion rate is increased when the flow rate reduced from 150 to $50 \mathrm{ml} / \mathrm{min}$

\section{Conclusions}

The Performance of the carbon prepared from three types of tree branches as adsorbents to removed nitrophenol from aqueous solution have been investigated. Equilibrium isotherms have been measured. The experimental isotherm data were analysis using Langmuir, Freundlich and Temkin equations.

Due to the inherent bias of the using the correlation coefficient resulting from linearization, alternative single component parameters were determined by non-linear regression employment in this study. The error function used is the Marquardt's percent standard deviation. The values obtained from the error function showed that, the experimental isotherm data are well described by Temkin model and to lower degree by Langmuir and Freundlich respectively.

The fixed bed column performance of the Acacia carbon (AC) for the removal of nitrophenol was carried out. The column studies data has a good agreement with the BDST model. The model can be used to predict the break time at different bed height.

The EBRT model was applied to optimize the operating system conditions. There is a significant gain in the exhaustion rate using on reducing the nitrophenol solutions flow rates, and optimum conditions can be obtained by maximizing the adsorbent utilization rate.

\section{References}

[1] Salvador F, Merchan M D, Study of the desorption of phenol and phenolic compounds from activated carbon by liquid phase temperature-programmed desorption, Carbon, 34 (1996) 1543-1551.

[2] Ribeiro A, Neves MH, Almeida MF, Alves A, Santos L., Direct determination of chlorophenols in landfill leachates by solid-phase micro-extraction-gas chromatographymass spectrometry, J Chromatogr. A, 975 (2002) 267-274.

[3] Calace N, Nardi E, Petronio BM, Pietroletti M. Adsorption of phenols by papermill sludges, Environ Pollut,118 (2002) 315-319. 
[4] S.S. Adav, M. Chen, D. Lee, N. Ren, Degradation of phenol by aerobic granules and isolated yeasr candidat ropicalis, Biotechnol. Bioeng., 96 (2007) 844-852.

[5] N.Z. Al-Mutairi, 2,4-Dinitrophenol adsorption by date seeds: Effect of physico-chemical environment and regeneration study, Desalination 250 (2010) 892-901

[6] J. Wang, W. Zhu, S. Yang, W. Wang, Y. Zhou, Catalytic wet air oxidation of phenol with pelletized ruthenium catalysts, Appl. Catal. B: Environ., 78 (2008) 30- 37.

[7] G.P. Prpich, A.J. Daugulis, Enhanced biodegrading of phenol by microbial consortun in solid-liquid two phase partitioning bioreactor, Biodegradation ,16 (2005) 329-339.

[8] S. Pura, G. Atun, Enhancement of nitrophenol adsorption in the presence of anionic surfactant and the effect of the substituent position, Colloids Surf. A: Physicochem. Eng. Asp., 253 (2005) 137-144.

[9] C. Hong,W. Zhang, B.Pan, L.Lu,Y.Han and Q Zhang, adsorption and desorption hysteresis of 4-nitrophenol on Hyper-cross-polymer resin, Journal of Hazardous Material, 168 (2009),2-3,1217-1222.

[10] W. S. Wan Ngah h, S. Fatinathan, Chitosan flakes and chitosan-GLA beads for adsorption of p-nitrophenol in aqueous solution, Colloids Surf. A: Physicochem. Eng. Asp., 277 (2006) 214-222.

[11] S. Dutta, J. K. Basu, R. N. Ghar, Studies on adsorption of p-nitrophenol on charred sawdust, Sep. Purif. Technol., 21 (2001) 227-235.

[12] A. R. El-Gamil, Waste treatment of liquid/solid pollutions, M Sc thesis, Dep. of Chemical Engineering, Faculty of Engineering, Minia University, (2002).

[13] Langmuir,I., "The constitution and fundamental properties of solids and liquids", J. Am. Chem. Soc., 38 ,11 (1916) 2221 .

[14] H.M.F. Freundlich, H.M.F. Über die adsorption in lösungen, Zeitschrift fǘr Physikalische Chemie. 57, (1906) 385.

[15]Temkin,M. J., Pyzhev, V., "Kinetics of ammonia synthesis on promoted iron catalysis",Acta Physiochim. URSS, 12 (1940), 327-356.

[16] Weber,T.W. and Chakravorti, R.K., Pore and solid diffusion model for fixed bed absorbers. AIChE J, 20, 2, (1974) 2228.

[17] Treybal, R. E., Mass transfer operation, 3rd ed., McGraw-Hill Book Company, New York (1980)

[18] Marquardt, D. W., An algorithm for least squares estimation of non-linear paramteres, J.Soc. Ind. App. Maths., 11 (1963) 431-441.

[19] Mamdouh M. Nassar, Kamal T. Awida, Ebrahiem E. Ebrahiem, Yehia H. Magdy and Mansour H. Meheadi, Fixed-bed Adsorption for Removal of Iron and Manganese onto Palm Fruit Bunch and Maize Cob, Adsorption Science \& Technology , 22 (2003) 161175.

[20] Hutchins, R.A., New simplified design of activated carbon system, Am. J. Chem. Eng., 80(1973) 133.

[21] McKay, G., Use of Adsorbents for the Removal of Pollutants from Wastewaters, McKay, Ed. CRC Press: Bora Raton, Fl, (1996). 


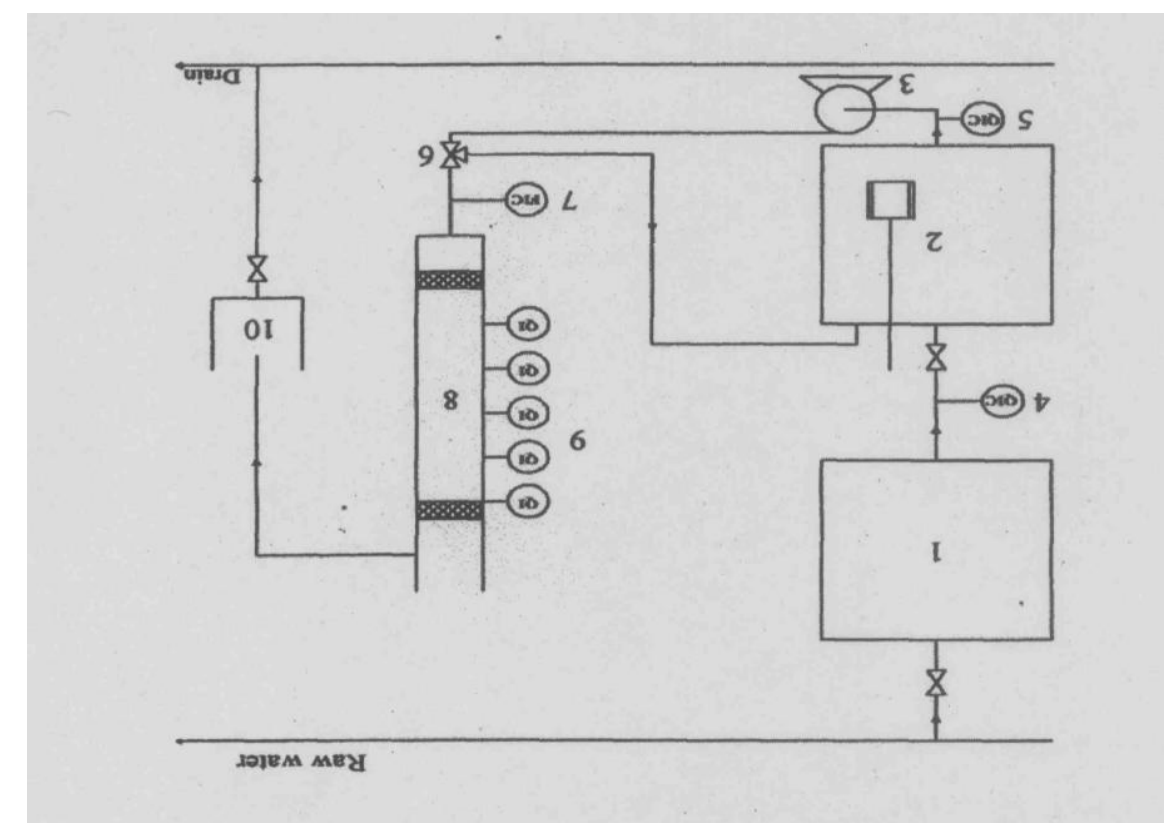

Figure 1: Schematic diagram for fixed bed adsorber unit;

Calibrated plastic container, 2- a $40 \mathrm{dm}^{3}$ container with mechanical agitation, 3- Centrifugal pump, 4, 5 - Sampling points to check up the initial influent nitrophenol concentration, 6Three-way valve connected to overflow line, 7- Rotameter, 8- Glass column $50 \mathrm{~cm}$ height and $3 \mathrm{~cm}$ diameter, 9- Sampling points sub-seals for syringe (distance from perforated mesh to the first sampling point is $10 \mathrm{~cm}$ then distance apart $5 \mathrm{~cm}$ each), 10- Effluent collection vessel

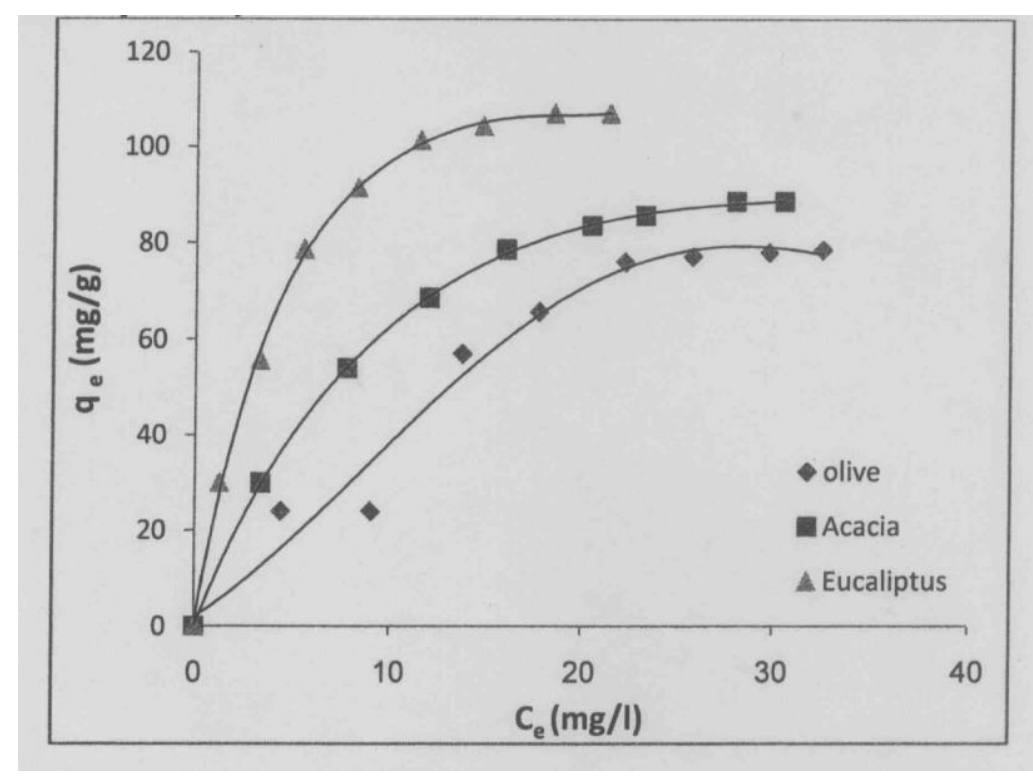

Figure 2: Adsorption isotherm of nitrophenol onto different types of carbon. 


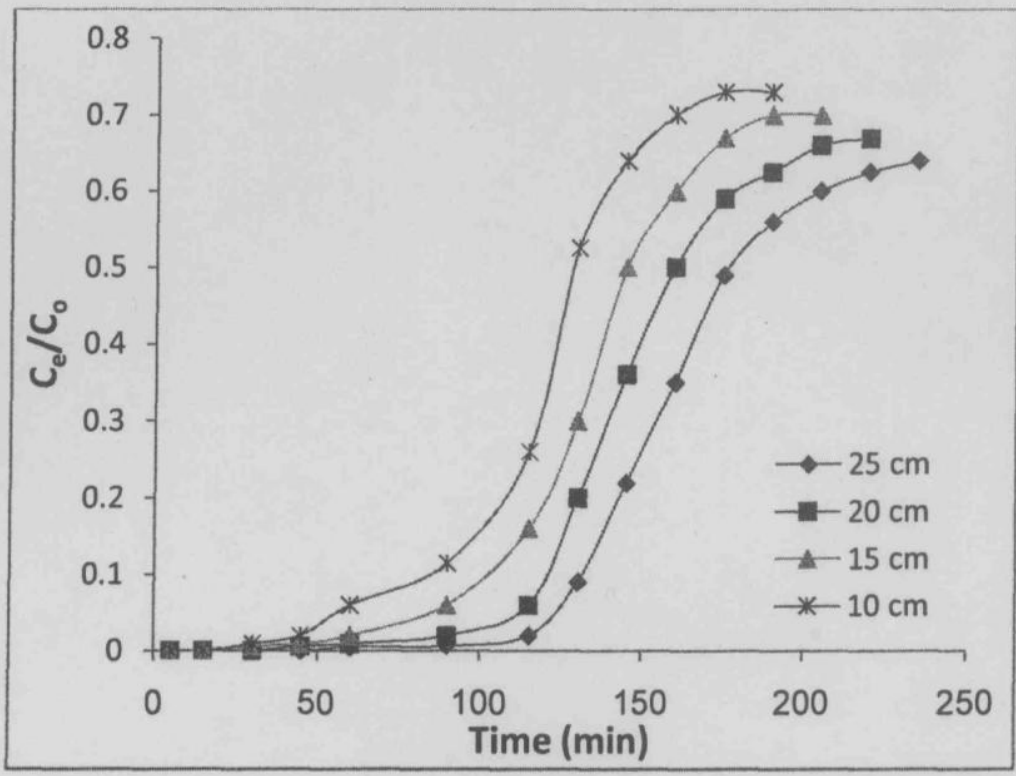

Figure 3: Breakthrough curves for the adsorption of nitrophenol (NP) onto Acacia carbon $(\mathrm{AC})$ at $\mathrm{C}_{\mathrm{o}}=40 \mathrm{mg} / \mathrm{l}$, flow rate $50 \mathrm{ml} / \mathrm{min}$.

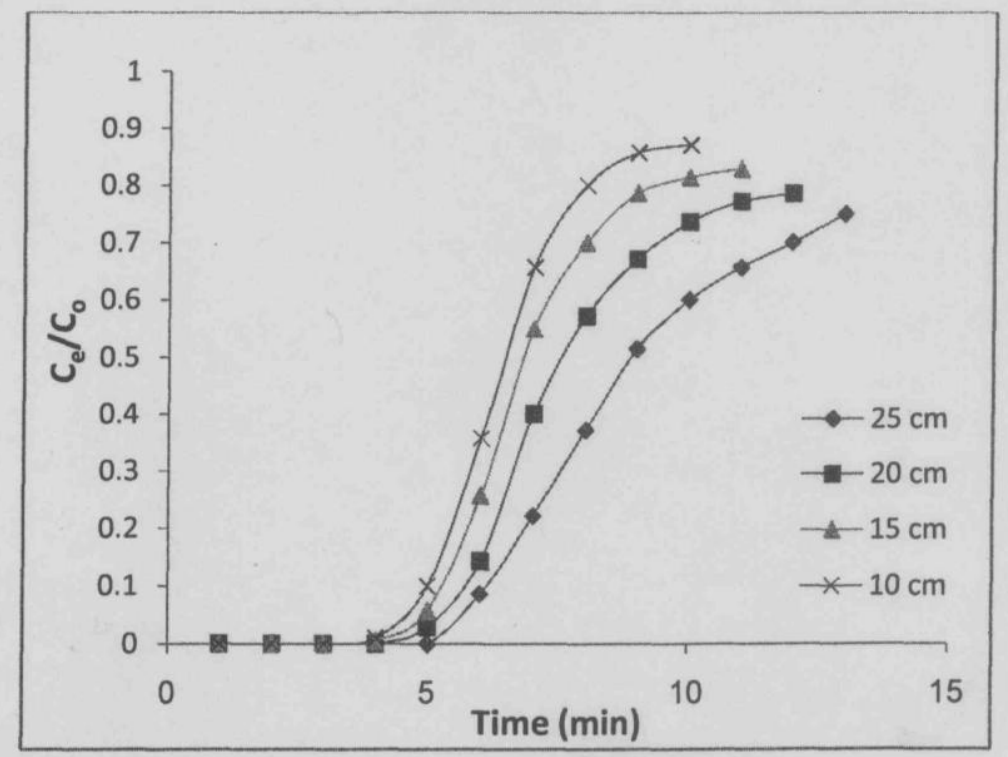

Figure 4: Breakthrough curves for the adsorption of nitrophenol (NP) onto Acacia carbon $\left(\mathrm{AC}\right.$ ) at $\mathrm{C}_{\mathrm{o}}=40 \mathrm{mg} / \mathrm{l}$, flow rate $100 \mathrm{ml} / \mathrm{min}$. 


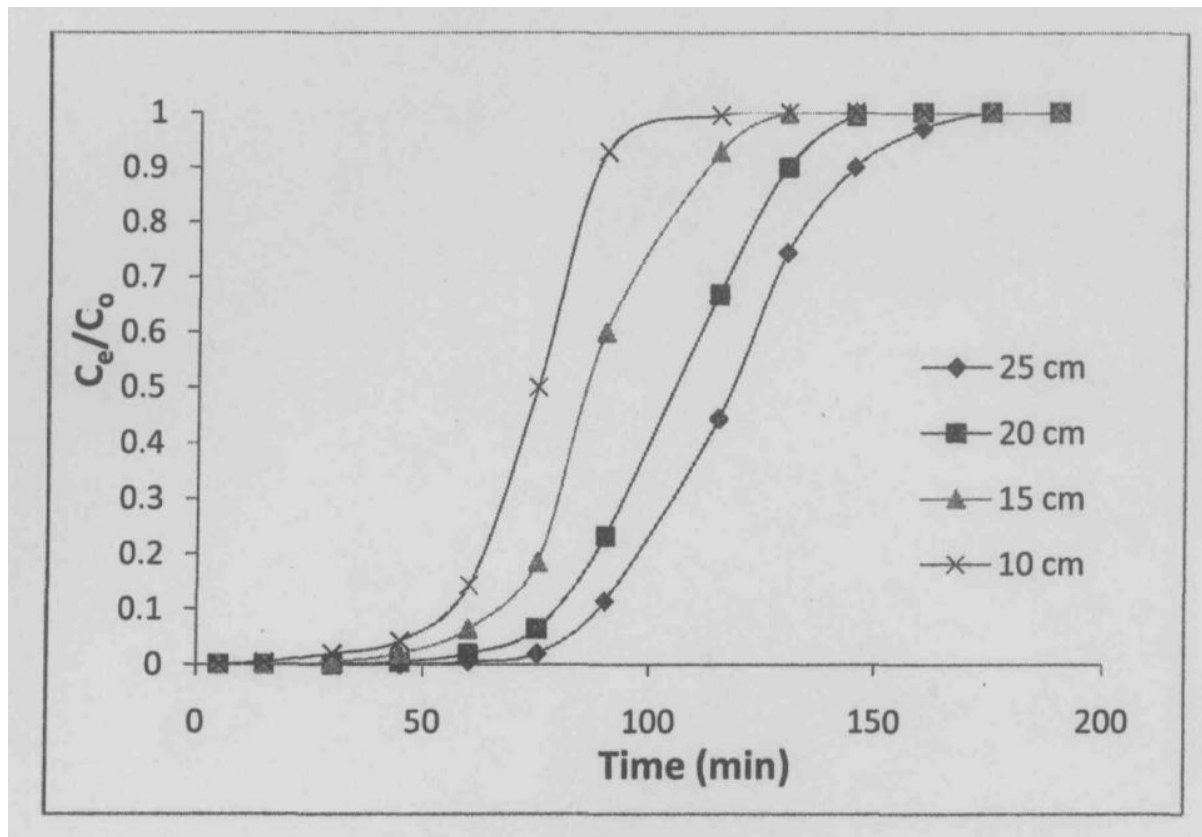

Figure 5: Breakthrough curves for the adsorption of nitrophenol (NP) onto Acacia carbon $(\mathrm{AC})$ at $\mathrm{C}_{\mathrm{o}}=40 \mathrm{mg} / \mathrm{l}$, flow rate $150 \mathrm{ml} / \mathrm{min}$.

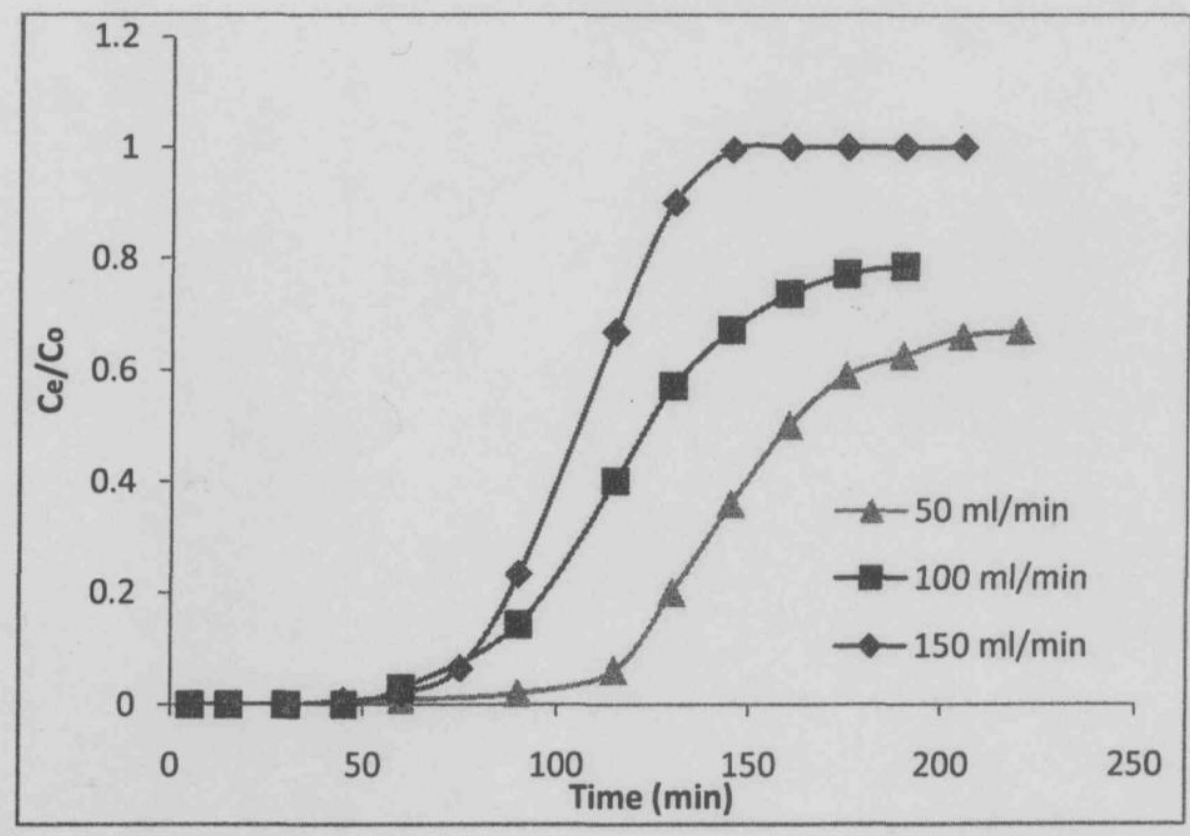

Figure 6: Breakthrough curves for the adsorption of nitrophenol (NP) onto Acacia carbon (AC) at $\mathrm{C}_{\mathrm{o}}=40 \mathrm{mg} / \mathrm{l}$, bed depth $20 \mathrm{~cm}$, different flow rates. 


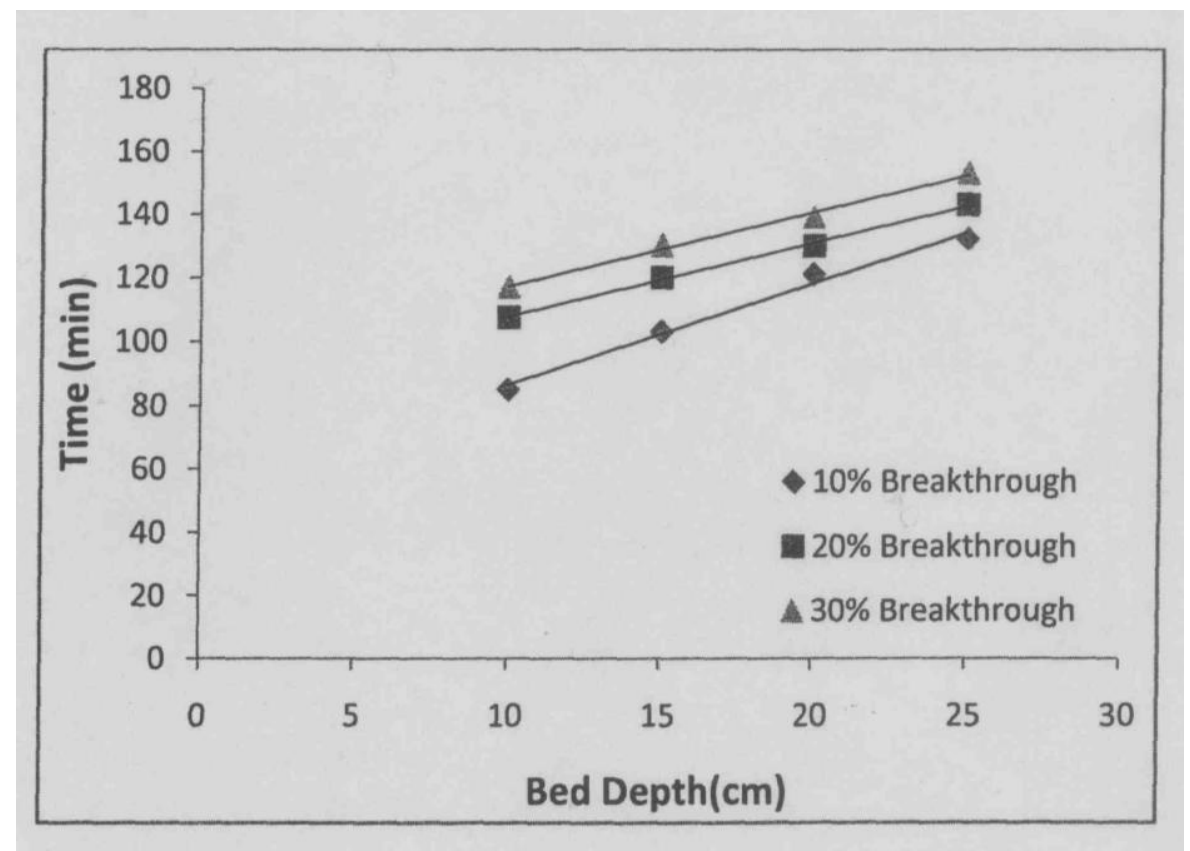

Figure 7: BDST model for nitrophenol (NP) onto Acacia carbon (AC) at $\mathrm{C}_{\mathrm{o}}=40 \mathrm{mg} / \mathrm{l}$, different breakthrough and flow rate $50 \mathrm{ml} / \mathrm{min}$.

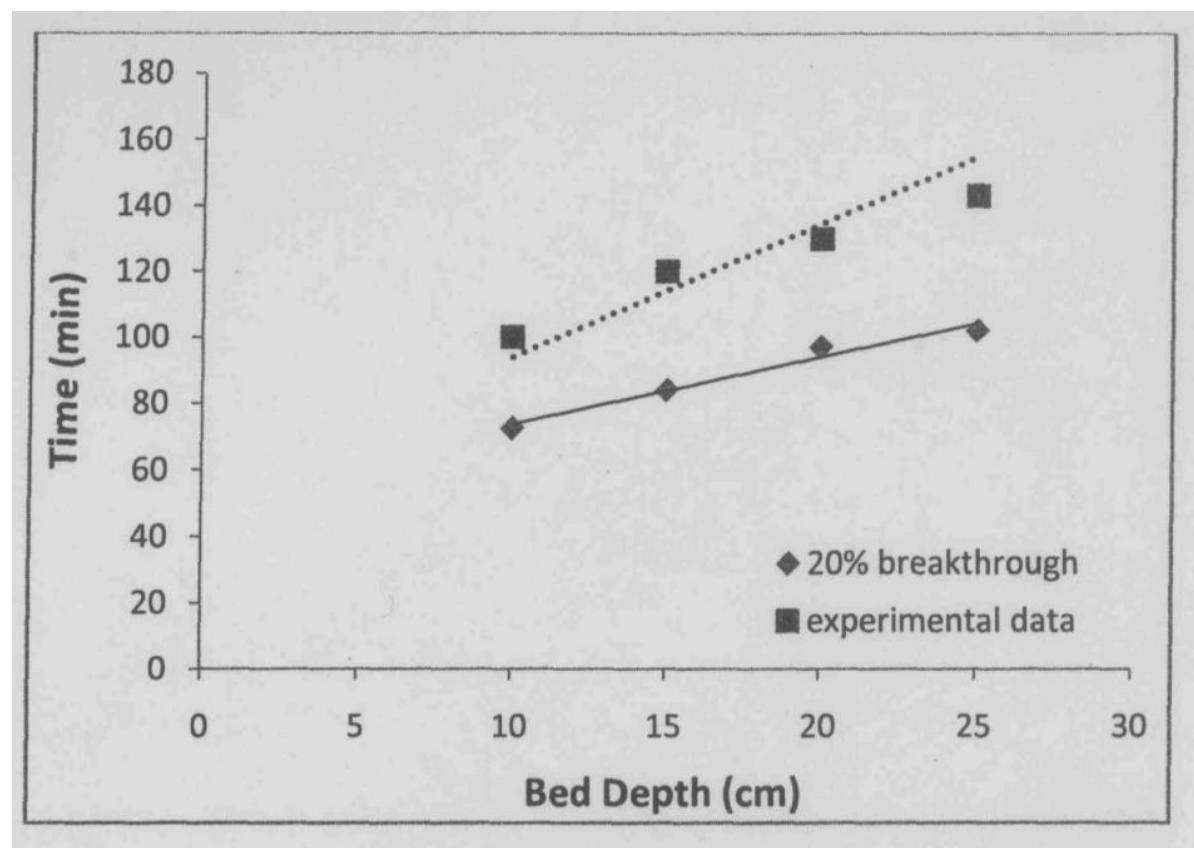

Figure 8: Theoretical predicted line at flow rate $=50 \mathrm{ml} / \mathrm{min}$ and $20 \%$ breakthrough, from solid line at flow rate $=100 \mathrm{ml} / \mathrm{min}$ and $20 \%$ breakthrough for nitrophenol and comparison with the experimental data. 


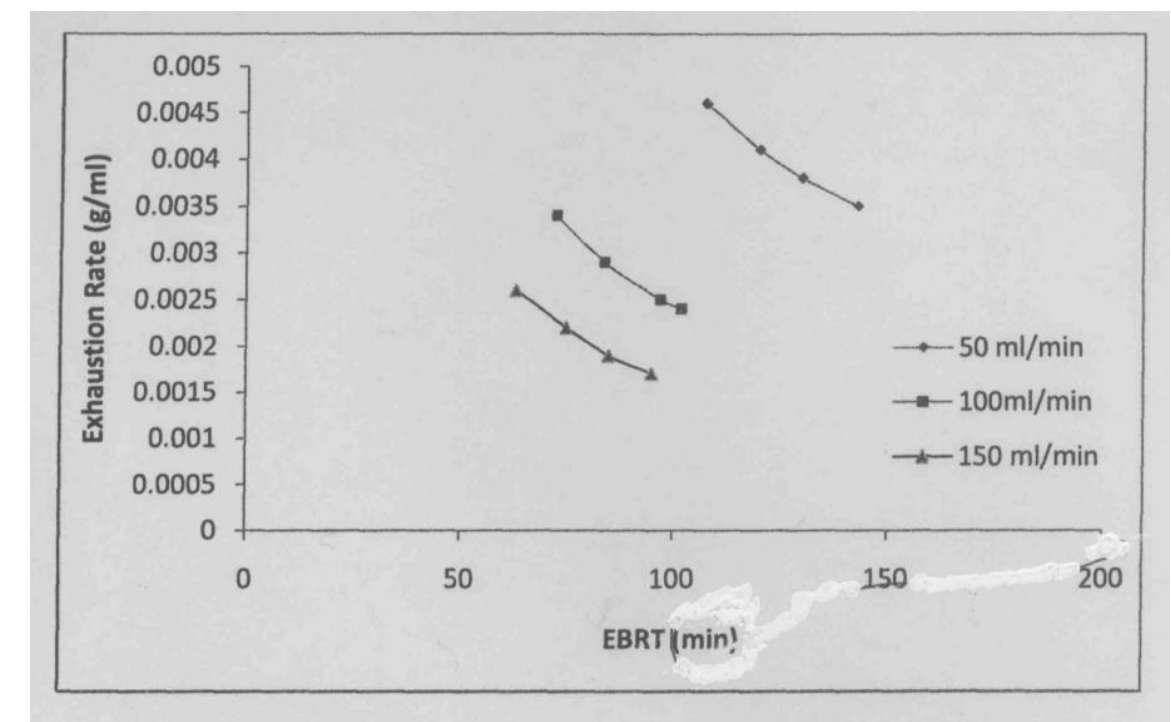

Figure 9: Operating lines depicting the influence of flow rate of nitrophenol at $\mathrm{Co}=40 \mathrm{mg} / \mathrm{l}, 20 \%$ breakthrough.

Table 1: Isotherms and their linear forms

\begin{tabular}{|c|c|c|}
\hline Isotherms & Linear Form & References \\
\hline Langmuir & & [13] \\
\hline Freundlich & & [14] \\
\hline Temkin & & [15] \\
\hline
\end{tabular}

Table 2: Isotherms constant in Langmuir adsorption model

\begin{tabular}{|c|c|c|c|l|}
\hline $\begin{array}{c}\text { Correlation } \\
\text { Coefficient }\end{array}$ & $\begin{array}{c}\mathbf{R}_{\mathbf{L}} \\
(-)\end{array}$ & $\begin{array}{c}\mathbf{a}_{\mathbf{L}} \\
(\mathbf{l} / \mathbf{m g})\end{array}$ & $\begin{array}{c}\mathbf{K}_{\mathbf{L}} \\
(\mathbf{l} / \mathbf{g})\end{array}$ & Carbon origin \\
\hline 0.98 & 0.294 & 0.06 & 7.51 & Olive (OC) \\
\hline 0.99 & 0.191 & 0.106 & 13.33 & Eucalyptus (EC) \\
\hline 0.99 & 0.094 & 0.241 & 34.48 & Acacia (AC) \\
\hline
\end{tabular}

Table 3: Isotherms constant in Freundlich adsorption model

\begin{tabular}{|c|c|c|l|}
\hline $\begin{array}{c}\text { Correlation } \\
\text { Coefficient }\end{array}$ & $\begin{array}{c}\mathbf{n} \\
(-)\end{array}$ & $\begin{array}{c}\mathbf{K}_{\mathbf{f}} \\
(\mathbf{l} / \mathbf{g})\end{array}$ & Carbon origin \\
\hline 0.93 & 1.412 & 7.493 & Olive (OC) \\
0.97 & 2.05 & 18.52 & Eucalyptus (EC) \\
\hline 0.96 & 2.24 & 31.46 & Acacia (AC) \\
\hline
\end{tabular}


Table 4: Isotherms constant in Temkin adsorption model

\begin{tabular}{|c|c|c|l|}
\hline $\begin{array}{c}\text { Correlation } \\
\text { coefficient }\end{array}$ & $\begin{array}{c}\text { B } \\
(-)\end{array}$ & $\begin{array}{c}\text { A } \\
(\mathbf{l} / \mathbf{m g})\end{array}$ & \multicolumn{1}{|c|}{ Carbon origin } \\
\hline 0.99 & 28.64 & 1.84 & Olive (OC) \\
\hline 0.99 & 27.63 & 1.07 & Eucalyptus (EC) \\
\hline 0.99 & 28.83 & 1.53 & Acacia (AC) \\
\hline
\end{tabular}

Table 5: Values of MPSD for isotherm models

\begin{tabular}{|c|c|c|l|}
\hline $\begin{array}{c}\text { Temkin } \\
3.80\end{array}$ & $\begin{array}{c}\text { Freundlich } \\
24.6\end{array}$ & $\begin{array}{c}\text { Langmuir } \\
34.30\end{array}$ & $\begin{array}{c}\text { Carbon origin } \\
\text { Olive (OC) }\end{array}$ \\
\hline 4.00 & 9.26 & 6.84 & Eucalyptus (EC) \\
\hline 6.20 & 12.7 & 10.14 & Acacia (AC) \\
\hline
\end{tabular}


Military Technical College

Kobry El-Kobbah, Cairo, Egypt

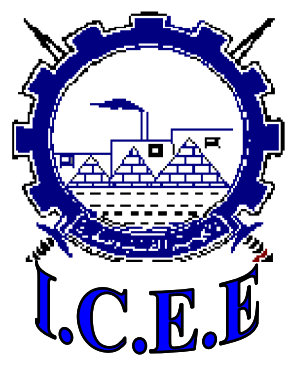

$5^{\text {th }}$ International Conference on

Chemical \& Environmental Engineering 25 - 27 May, 2010. 